\title{
MODEL PENINGKATAN KNOWLEDGE SHARING BERBASIS MODAL SOSIAL DAN LEARNING ORGANIZATIONTERHADAP KINERJA AGENCY PADA PT PRUDENTIAL LIFE ASSURANCE
}

\author{
Athoillah \\ Universitas Islam Sultan Agung Semarang \\ muhammadathoillah95@gmail.com
}

\begin{abstract}
The role of human resources reliable and professional in order to increase performance is needed, because it will affect the survival of the company. The phenomenon that often occurs in PT Prudential Life Assurance is the declining performance of the agency in the search for life insurance customers indicated by the number of customers. The purpose of this research is to investigate and analyze the influence of social capital and learning organization of the agency's performance in PT Prudential Life Assurance with knowledge sharing as an intervening variable. The population is all the marketing power PT Prudential HD Agency Semarang are still active by 67 employees. Given a population of only 67 employees, it deserves to be taken as a whole to be sampled, so this study is a census study. A tool of analysis is path analysis, which previously tested the validity and reliability and classic assumption test. The test results indicate social capital proved to have a positive effect and significant knowledge sharing. Learning organization has a positive and significant impact on knowledge sharing. Social capital, learning organization and knowledge sharing proved to have a positive and significant impact on the performance of the agency. Knowledge sharing is not able to become an intervening variable between social capital with the performance of the agency. Knowledge sharing is able to become an intervening variable between learning organization with the performance of the agency, meaning that the higher awareness of the company in increasing the capacity of learning for employees, it will raise the height of employees to share knowledge and it certainly will impact on the high performance of the agency.
\end{abstract}

Keywords: Social capital, learning organization, knowledge sharing and performance agency

\section{PENDAHULUAN}

Kinerja adalah hasil kerja secara kualitas dan kuantitas yang dicapai oleh seorang pegawai dalam melaksanakan tugasnya sesuai dengan tanggung jawab yang diberikan kepadanya(Mangkunegara,2012). Kinerja sumber daya manusia

Tujuan utama perusahaan didirikan adalah untuk mendapatkan keuntungan dari hasil usahanya, dan selanjutnya mampu berkembang dengan pesat serta mampu bersaing dengan perusahaan lain. Untuk mencapai keberadaan dan keberhasilan suatu organisasi dalam mencapai tujuannya, tidak dapat lepas dari faktor sumber daya manusianya. Hal ini karena sumber daya manusialah yang melaksanakan dan mengatur kegiatan organisasi tersebut. Begitu pentingnya peranan sumber daya manusia mengakibatkan suatu organisasi harus mengalokasikan sejumlah dana yang cukup besar untuk peningkatan sumber daya manusia tersebut.

Seiring dengan perkembangan ilmu 
pengetahuan dan teknologi yang semakin pesat, maka dituntut sumber daya manusia yang berkualitas. Keberhasilan suatu organisasi dalam mencapai tujuannya juga tergantung faktor sumber daya manusia, dimana dibutuhkan suatu interaksi dan koordinasi yang didesain untuk menghubungkan tugas-tugas, baik perseorangan maupun kelompok dalam rangka mencapai tujuan organisasi. Untuk mewujudkan tujuan yang diinginkan tersebut, maka salah satu cara yang harus ditempuh adalah dengan meningkatkan kinerjasumber daya manusia.

Kinerja adalah hasil kerja secara kualitas dan kuantitas yang dicapai oleh seorang pegawai dalam melaksanakan tugasnya sesuai dengan tanggung jawab yang diberikan kepadanya(Mangkunegara, 2012). Kinerja sumber daya manusia memegang peranan sebagai media untuk melancarkan pelaksanaan kegiatan usaha tersebut. Peranan sumber daya manusia yang handal dan profesional dalam usaha meningkatkan kinerja sangat dibutuhkan sekali, karena hal itu akan mempengaruhi kelangsungan hidup perusahaan.Pencapaian tujuan itu sangat bergantung pada kemampuan kinerja manajemen dalam melaksanakan fungsi - fungsi manajemen yaitu perencanaan, pengstrukturorganisasian dan pengendalian. Keberhasilan kinerja karyawan pada perusahaan dipengaruhi beberapa faktor, diantaranya karena faktor interaksi dan komunikasi untuk saling berbagi, hubungan antar karyawan sehingga terjalin kerjasama yang saling menguntungkan serta pentingnya pembelajaran organisasi.

Knowledge Sharing merupakan interaksi dan komunikasi antara individu dan unit bisnis (Reed, Srinivasan dan Doty 2009). Untuk mendukung knowledge sharing yang efektif, perusahaan haruslah membangun komunikasi (sosial dan teknikal) yang baik dan memungkinkan individu ataupun kelompok untuk berinteraksi dengan lancar. Keberhasilan knowledge sharing tergantung dari kuantitas dan kualitas interaksi diantara karyawan dan kemauan serta kemampuan menggunakan pengetahuan. Organisasi seharusnya mendorong tujuan karyawan dan tujuan organisasi, kemudian menterjemahkan tujuan tersebut ke dalam teknis dan mempromosikan karyawan.

Modal sosial dalam perusahaan dicirikan oleh adanya interaksi sosial timbal balik diantara karyawan dan manajemen dan antarsesama keduanya.Terbentuknya modal sosial sangat bergantung pada mutu sumberdaya manusia para karyawannya. Semakin meningkatnya mutu SDM diharapkan akan semakin terbentuknya rasa kebersamaan, kesetiakawanan, dan sekaligus tanggungjawab akan kemajuan bersama.Bentuk interaksi itu didasarkan pada adanya rasa percaya sesama yang mengakar dalam suatu budaya organisasi dan etika sosial. Karena ada rasa percaya maka timbul suatu entitas karyawan (manajemen dan non-manajemen) yang memiliki kebersamaan tentang nilai-nilai kejujuran, kedisiplinan, kebersamaan, dan pentingnya kerja keras-cerdas dalam meningkatkan kinerja yang dihasilkan. Hal ini sesuai pernyataan Akdere (2005) dalam Yosna (2013) bahwa eksistensi modal sosial karyawan menjadi penting karena mempengaruhi kinerja karyawan yang pada gilirannya mempengaruhi kinerja organisasi.

Pembelajaran organisasional mewajibkan SDM untuk menggunakan waktu organisasi guna mengejar pengetahuan diluar cakupan kerja mereka . Jika organisasi tidak mendorong pengembangan pengetahuan, SDM tidak akan termotivasi untuk melakukan aktivitas belajar ((Calcantone, Cavusgil . and Zhao, 2002 dalam Widjayanti dan Widodo, 2014). Organisasi seharusnya mendorong tujuan karyawan dan tujuan organisasi, kemudian menterjemahkan tujuan tersebut ke dalam teknis dan mempromosikan karyawan. Menurut Che Rose et al. (2009) dalam Uniati (2014) bahwa Learning Organization (LO) menggambarkan bahwa learning (pembelajaran) adalah prasyarat atas 
keberhasilan terjadinya sebuah perubahan dan kinerja organisasi.

Penelitian tentang kinerja SDM telah banyak dilakukan oleh banyak peneliti, seperti yang dilakukan oleh Stam dan Elfring (2008), Wahyuningrum (2013) dan Khoirini dan Kartika (2014) yang menyatakan bahwa modal sosial memiliki pengaruh terhadap kinerja karyawan. Begitu halnya dengan penelitian yang dilakukan oleh Edy, dkk (2013) bahwa modal sosial berpengaruh positif terhadap kinerja aparatur.Sedangkan hasil penelitian Sukoco dan Hardi (2013) yang menunjukkan sebaliknya bahwa modal sosial tidak berpengaruh terhadap kinerja karyawan.

HasilpenelitianUniati(2014)menunjukkan bahwa pembelajaran organisasi justru tidak mampu mempengaruhi kinerja SDM. Sedangkan penelitian Makrufah (2011) justru sebaliknya bahwa pembelajaran organisasi mempunyai pengaruh positif terhadap kinerja karyawan. Hasil penelitian Fitriyana (2012) dan Zaied (2012) bahwa berbagi pengetahuan tidak berpengaruh terhadap kinerja bisnis, sedangkan Maharani dan Susanti (2013) bahwa knowledge sharing berpengaruh terhadap kinerja bisnis.

\section{TINJAUAN PUSTAKA \\ Kinerja SDM}

Simamora (2012) menjelaskan pengertian kinerja sebagai tingkat terhadap para staf mencapai persyaratanpersyaratan pekerjaan", Pengertian lain menurut Mangkunegara (2012), bahwa kinerja adalah hasil kerja secara kualitas dan kuantitas yang dicapai oleh seorang pegawai dalam melaksanakan tugasnya sesuai dengan tanggung jawab yang diberikan kepadanya. Sesuai dengan pengertian tersebut, mengandung tiga aspek yang perlu dipahami oleh setiap pegawai dan pimpinan dalam suatu organisasi yaitu (1) kejelasan tugas atau pekerjaan yang menjadi tanggung jawabnya; (2) kejelasan hasil yang diharapkan dari suatu pekerjaan atau fungsi; (3) waktu yang diperlukan untuk menyelesaikan suatu pekerjaan agar hasil yang diharapkan dapat terwujud.

Menurut Riduwan (2009) bahwa indikator yang digunakan untuk menilai kinerja karyawan antara lain adalah sebagai berikut:

\section{Inisiatif mencari langkah yang terbaik}

Inisiatif mencari langkah yang terbaik merupakan faktor penting dalam usaha untuk meningkatkan kinerja karyawan. Untuk memiliki inisiatif dibutuhkan pengetahuan serta ketrampilan yang dimiliki para karyawan dalam usaha untuk meningkatkan hasil yang dicapainya.

\section{Menguasai Job Description.}

Faktor kesesuaian antara disiplin ilmu yang dimiliki dengan penempatan pada bidang tugas.

\section{Hasil yang dicapai}

Kemampuan untuk mengatur pekerjaan yang menjadi tanggung jawabnya termasuk membuat jadwal kerja, umumnya mempengaruhi kinerja seorang karyawan

\section{Tingkat kemampuan kerjasama}

Kemampuan bekerjasama dengan karyawan maupun orang lain, karena dalam hal ini sangat berperan dalam menentukan kinerjanya

\section{Ketelitian}

Ketelitian yang tinggi yang dimiliki karyawan dalam menyelesaikan pekerjaan dapat meningkatkan kinerjanya

\section{Tingkat kesesuaian tugas dengan perintah}

Adanya kesesuaian antara tugas yang diberikan pimpinan terhadap kemampuan karyawan dapat menentukan kinerja karyawan

\section{Tingkat kualitas hasil kerja \\ Pekerjaan yang dilakukan dengan kualitas yang tinggi dapat memuaskan yang bersangkutan dan perusahaan.}


Penyelesaian tugas yang terandalkan, tolok ukur minimal kualitas kinerja pastilah dicapai.

\section{Tingkat ketepatan penyelesaian kerja}

Tingkat suatu aktivitas diselesesaikan pada waktu awal yang diinginkan, dilihat dari sudut koordinasi dengan hasil output serta memaksimalkan waktu yang tersedia untuk aktivitas lain.

\section{Tingkat kuantitas hasil kerja}

Pekerjaan yang dilakukan karyawan harus memiliki kuantitas kerja tinggi dapat memuaskan yang bersangkutan dan perusahaan. Dengan memiliki kuantitas kerja sesuai dengan yang ditargetkan, maka hal itu akan dapat mengevaluasi kinerja karyawan dalam usaha meningkatkan prestasi kerjanya.

\section{Modal Sosial}

Fukuyama (Sukoco dan Hardi, 2013) merumuskan modal sosial dengan mengacu kepada "norma-norma informal yang mendukung kerjasama antara individu dan kapabilitas yang muncul dari prevalensi kepercayaan dalam suatu masyarakat atau di dalam bagian-bagian tertentu dari masyarakat.Sedangkan Coleman (Field, 2005) mengartikan modal sosial (social capital) sebagai struktur hubungan antar individu-individu yang memungkinkan mereka menciptakan nilai-nilai baru.

Modal sosial dapat dijelaskan sebagai produk relasi manusia satu samalain, khususnya relasi yang intim dan konsisten. Modal sosial menunjuk pada jaringan, norma dan kepercayaan yang berpotensi pada produktivitas masyarakat. Ridell (1997), ada tiga parameter modal sosial, yaitu :

\section{Kepercayaan (trust)}

Fukuyama (1995), kepercayaan adalah harapan yang tumbuh di dalam sebuah masyarakat yang ditunjukkan oleh perilaku jujur, teratur, dan kerjasama berdasarkan norma-norma yang dianut bersama.

\section{Norma-norma (norms)}

Norma-norma terdiri dari pemahamanpemahaman, nilai-nilai, harapan-harapan dan tujuan-tujuan yang diyakini dan dijalankan bersama oleh sekelompok orang. Norma-norma dapat bersumber dari agama, panduan moral, maupun tandar-standar sekuler seperti halnya kode etik profesional. Norma-norma dibangun dan berkembang berdasarkan sejarah kerjasama di masa lalu dan diterapkan untuk mendukung iklim kerjasama (Putnam, 1993; Fukuyama, 1995)

\section{Jaringan-jaringan (networks).}

Infrastruktur dinamis dari modal sosial berwujud jaringan-jaringan kerjasama antar manusia (Putnam, 1993).Jaringan tersebut memfasilitasi terjadinya komunikasi dan interaksi, memungkinkan tumbuhnya kepercayaan dan memperkuat kerjasama. Masyarakat yang sehat cenderung memiliki jaringan-jaringan sosial yang kokoh. Orang mengetahui dan bertemu dengan orang lain. Mereka kemudian membangun inter-relasi yang kental, baik bersifat formal maupun informal (Onyx, 1996). Putnam (1995) berargumen bahwa jaringan-jaringan sosial yang erat akan memperkuat perasaan kerjasama para anggotanya serta manfaatmanfaat dari partisipasinya itu.

\section{Learning Organization}

\begin{tabular}{lcr}
\multicolumn{1}{c}{ Perusahaan yang } & melakukan \\
pembelajaran & organisasi & adalah \\
perusahaanyang & memiliki & keahlian \\
dalam menciptakan, mengambil, dan
\end{tabular}
mentransferpengetahuan, dan memodifikasi perilakunya untuk merefleksikan pengetahuandan pengalaman barunya. Learning Organization (LO) menggambarkan bahwa learning (pembelajaran) adalah prasyarat atas keberhasilan terjadinya sebuah perubahan dan kinerja organisasi (Che Rose et al. 2009). Pembelajaran dapat meningkatkan kapabilitas intelektual staf sehingga organisasi menjadi lebih baik karena memiliki staf yang senantiasa belajar, (Watkins and Marsick, 1997 dalam 
Uniati, 2014).

Menurut Watkins and Marsick (2003) dalam Uniati (2014) pembelajaran organisasi dapat diartikan sebagai sebuah system integratif yang diterapkan di tempat kerja dan lingkungan untuk mendukung proses belajar. Learning Organization (LO) menggambarkan bahwa learning (pembelajaran) adalah prasyarat atas keberhasilan terjadinya sebuah perubahan dan kinerja organisasi (Che Rose et al. 2009).

Menurut Mikkelsen, et al (2000) dalam Mas'ud (2004) bahwa pembelajaran organisasi dapat diukur antara melalui hubungan dan gaya kepemimpinan, waktu, otonomi dan tanggung jawab, gaya tim, kesempatan untuk berkembang, pedoman dalam bagaimana melaksanakan pekerjaan dan kesenangan.

\section{Knowledge Sharing}

Hoof dan Weenen (2004) mendefinisika knowledge sharing sebagai aktivitas para individu saling bertukar intelectual capital personal. Berbagai pengetahuan (knowledge sharing) pada dasarnya sebuah prinsipi pengorganisasian yang meletakkan dasar untuk menangkap potensi pengetahuan yang dimiliki dalam organisasi.Untuk membuat sebagian besar dari sumber daya organisasi dan meningkatkan berbagi pengetahuan adalah penting untuk mengakui bahwa mengelola teknologi dan orang-orang dalam rangka menyediakan lingkungan berbagi pengetahuan yang bermanfaat.Knowledge sharing bertujuan untuk melakukan sesuatu yang berguna oleh orang-orang, struktur, teknologi informasi dan isi pengetahuan.

Berbagi pengetahuan hanya dapat dilakukan bilamana setiap anggota memiliki kesempatan yang luas dalam menyampaikan pendapat, ide, kritikan dan komentarnya kepada anggota lainnya. Berbagi pengetahuan dapat tumbuh dan berkembang apabila menemukan kondisi yang sesuai.Sedangkan kondisi tersebut ditentukan oleh tiga faktor kunci yaitu orang, organisasi dan teknologi (Subagyo, 2007).Sebagain besar situs portal suatu organisasi, instansi atau perusahaan telah menggunakan fitur forum diskusi (discussion forum) untuk memberikan kesempatan yang luas kepada anggotanya dalam menyampaikan kesulitan yang dihadapi dalam pekerjaannya, ide-ide yang timbul untuk meningkatkan produktifitas pekerjaannya, kritikan dan saran terhadap organisasi dalam rangka menciptakan lingkungan kerja yang kondusif.

Menurut Shannak (2009), berbagi pengetahuan (knowledge sharing) dapat diukur antara lain dengan Perilaku Knowledge Sharing yang meliputi rutinitas dalam diskusi, bertukar pengalaman untuk memecahkan solusi dan penghematan waktu, serta aktivitas. Knowledge Sharing yaitu melalui berparsitipasi dalam mengikuti pertemuan, seperti kegiatan workshop, seminar, atau aktivitas lain.

\section{Model Empirik}

Dalam hal ini peneliti ingin mengetahui pengaruh antara modal sosial, learning organization terhadap kinerja agency denganknowledge sharing sebagai variabel interveningpada PT PRUDENTIAL LIFE ASSURANCE.

\section{Hipotesis Penelitian}

Berdasarkan pada landasan teori dan kerangka pemikiran di atas, hipotesis yang diajukan dalam penelitian ini adalah sebagai berikut :

$\mathrm{H} 1$ : Semakin tinggi modal sosial maka akan semakin menambah tingginya knowledge sharing.

$\mathrm{H} 2$ : Semakin tinggi learning organization maka akan semakin tinggi intensitas knowledge sharing.

H3 :Semakin tinggi modal sosial maka akan semakin meningkatkan kinerja agency.

$\mathrm{H} 4$ : Semakin tinggi learning organization maka akan semakin mampu meningkatkan kinerja agency. 


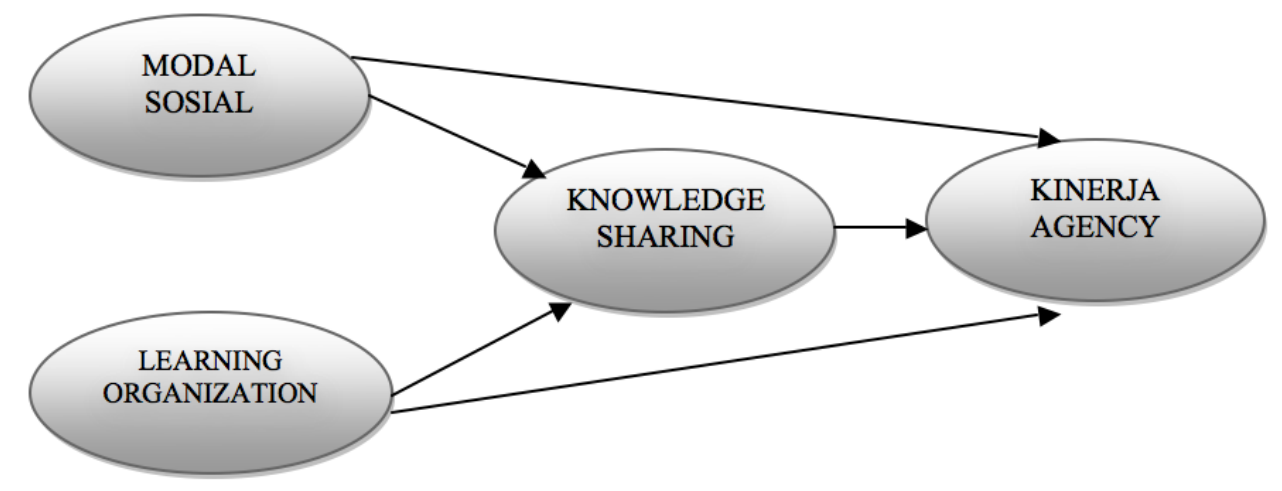

\section{Kerangka Pemikiran Teoritis}

H5: Semakin tinggi knowledge sharing maka akan semakin meningkatkan kinerja agency.

\section{METODE PENELITIAN}

Penelitian ini merupakan penelitian survei yang dimaksudkan untuk memberikan penjelasan atau Explanatory Research. Penelitian survey merupakan penelitian yang mengambil sampel dari suatu populasi dan menggunakan kuesioner sebagai alat pengumpulan yang pokok (Sugiyono, 2012). Metode pengumpulan data dalam penelitian ini menggunakan metode kuesioner, wawancara \& studi pustaka.

Mengingat populasi pada PT PRUDENTIAL LIFE ASSURANCE hanya sebesar 67 karyawan, maka layak untuk diambil secara keseluruhan untuk dijadikan sampel, sehingga penelitian ini merupakan penelitian sensus. Hal tersebut karena ditinjau dari wilayahnya penelitian ini hanya meliputi daerah atau subyek yang sangat sempit, sehingga peneliti merasa perlu untuk meneliti secara keseluruhan tanpa harus mengambil sampel dalam jumlah tertentu. (Arikunto, 2012).

Metode analisis yang digunakan untuk uji hipotesis dalam penelitian ini adalah path analysisyang berfungsi untuk mengetahui pengaruh langsung dan tidak langsung. Model path analisis (analisis jalur) merupakan perluasan dari analisis regresi linier berganda. Analisis jalur adalah penggunaan analisis regresi untuk menaksir hubungan kausalitas antar variabel (model causal) yang telah ditetapkan sebelumnya berdasarkan teori (Ghozali, 2013). Path analisis digunakan untuk menganalisis pola hubungan antar variable dengan tujuan untuk mengetahui pengaruh langsung maupun tidak langsung seperangkat variabel bebas (eksogen) terhadap variabel terikat (endogen).

Manfaat dari path analisis adalah untuk penjelasan terhadap fenomena yang dipelajari atau permasalahan yang diteliti, prediksi dengan path analisis ini bersifat kualitatif, faktor determinan yaitu penentuan variabel bebas mana yang berpengaruh dominan terhadap variable terikat, serta dapat menelusuri mekanisme pengaruh variable bebas terhadap variabel terikat.

\section{HASIL DAN PEMBAHASAN \\ Uji validitas}

Uji validitas (uji kesahihan) adalah suatu alat yang digunakan untuk mengukur sah I valid tidaknya suatu kuesioner (Ghozali, 2013).Untuk mengetahui kelayakan instrumen, maka kriteria pengambilan keputusan ditentukan dengan nilai $r$ hitung $>$ nilai $r$ tabel Hasil pengujian berdasarkan kriteria statistiknya valid karena $\mathrm{R}$ hitung pada setiap variable belih besar dari pada $\mathrm{R}$ tabel.

\section{Uji Reliabilitas}

Uji Reliabilitas adalah uji yang dipakai untuk menunjukkan sejauh mana suatu 
hasil pengukuran relatif konsisten apabila alat ukur yang digunakan berulang kali. Pengujian yang dipakai adalah dengan teori Cronbach Alpha. Suatu variabel dikatakan reliabel, jika memberikan nilai cronbach alpha >nilai standarisasi yang ditentukan sebesar 0,6 (Ghozali, 2013). Hasil pengujian
Nilai koefisien regresi antara learning organization terhadap knowledge sharing mempunyai nilai positif sebesar 0,457 , dapat diartikan bahwa semakin tinggi kesadaran perusahaan dalam meningkatkan kapasitas pembelajaran bagi karyawan, seperti atasan ikut terlibat, waktu, bertanggung jawab,

Tabel 1. Hasil Regresi

\begin{tabular}{cccccc}
\hline Variabel Terikat & Variabel Bebas & B & $\begin{array}{c}\mathbf{t} \\
\text { hitung }\end{array}$ & Sig & Keterangan \\
\hline \multirow{2}{*}{$\begin{array}{c}\text { Knowledge } \\
\text { sharing }\end{array}$} & $\begin{array}{c}\text { Modal sosial } \\
\text { Learning organization }\end{array}$ & 0,337 & 2,377 & 0,020 & Ha diterima \\
& & & 3,223 & 0,002 & Ha diterima \\
& Modal sosial & 0,231 & 2,371 & 0,021 & Ha diterima \\
Kinerja Agency & Learning organization & 0,372 & 3,700 & 0,000 & Ha diterima \\
& Knowledge sharing & 0,386 & 4,692 & 0,000 & Ha diterima \\
\hline
\end{tabular}

menggunakan program SPSS pada masingmasing variabel adalah reliabel karena nilai variabelnya lebih dari 0,6 (nilai standarisasi)

\section{Hasil Persamaan Regresi}

$$
\begin{aligned}
& Y_{1}=0,337 X_{1}+0,457 X_{2}+e \\
& Y_{2}=0,231 X_{1}+0,372 X_{2}+0,386 Y_{1}+e
\end{aligned}
$$

Hasil persamaan regresi dinyatakan dengan Standardized Coefficients dengan pertimbangan ukuran variabel bersifat kualitatif, sehinggadapat dijelaskan: Modal sosial $\left(X_{1}\right)$ dan learning organization $\left(X_{2}\right)$ berpengaruh positif terhadap knowledge sharing.

Hasil persamaan regresi terlihat bahwa nilai koefisien regresi untuk variabel modal sosial terhadap knowledge sharing menunjukkan nilai positif sebesar 0,337 , mempunyai arti bahwa semakin tinggi modal sosial, seperti adanya kepercayaan, normanorma dan jaringan-jaringan maka akan semakin terbentuknya rasa kebersamaan, kesetiakawanan, dan sekaligus tanggungjawab akan kemajuan bersama sehingga akan semakin menambah tingginya karyawan untuk saling berbagi pengetahuan. kemudahan bantuan dari tim, kesempatan berdiskusi, perlakuan secara adil dan mau berusaha dengan baik maka akan semakin menambah tingginya karyawan untuk saling berbagi pengetahuan.

Modal sosial $\left(X_{1}\right)$ dan learning organization $\left(\mathrm{X}_{2}\right)$ dan knowledge sharing $(\mathrm{Y} 1)$ berpengaruh positif terhadap kinerja agency

Nilai koefisien regresi untuk variabel modal sosial terhadap kinerja agency menunjukkan nilai positif yaitu sebesar 0,231 , mempunyai arti bahwa semakin tinggi modal sosial, seperti adanya kepercayaan, norma-norma dan jaringanjaringan maka akan semakin terbentuknya rasa kebersamaan, kesetiakawanan, dan sekaligus tanggungjawab akan kemajuan bersama, sehingga akan berdampak pada tingginya kinerja agency.

Nilai koefisien regresi untuk learning organization terhadap kinerja agency mempunyai nilai positif sebesar 0,372 , memberikan pengertian bahwa semakin tinggi kesadaran perusahaan dalam meningkatkan kapasitas pembelajaran karyawan, seperti atasan ikut terlibat, waktu, bertanggung jawab, kemudahan bantuan dari tim, kesempatan berdiskusi, perlakuan 
secara adil dan mau berusaha dengan baik maka akan semakin berdampak pada tingginya kinerja agency.

Nilai koefisien regresi untuk variabel knowledge sharing terhadap kinerja agency menunjukkan nilai positif yaitu sebesar 0,386 , mempunyai arti bahwa semakin tinggi karyawan tenaga pemasaran memiliki kesempatan yang luas dalam menyampaikan pendapat, ide, kritikan. seperti rutinitas dalam diskusi, bertukar pengalaman untuk memecahkan solusi, partisipasi dalam workshop akan meningkatkan kinerja agency.

\section{SIMPULAN}

Berdasarkan penelitian yang telah dilakukan maka dapat diperoleh kesimpulan sebagai berikut :

Modal sosial terbukti mempunyai pengaruh positif dan signifikan terhadap knowledge sharing, dapat diartikan bahwa semakin tinggi modal sosial, maka akan semakin terbentuknya rasa kebersamaan, kesetiakawanan, dan sekaligus tanggungjawab akan kemajuan bersama sehingga akan semakin menambah tingginya karyawan untuk saling berbagi pengetahuan.

Learning organization mempunyai pengaruh positif dan signifikan terhadap knowledge sharing, artinya semakin tinggi kesadaran perusahaan dalam meningkatkan kapasitas pembelajaran bagi karyawan, maka akan semakin menambah tingginya karyawan untuk saling berbagi pengetahuan.

Modal sosial terbukti mempunyai pengaruh positif dan signifikan terhadap kinerja agency, artinya semakin tinggi modal sosial, maka akan semakin terbentuknya rasa kebersamaan, kesetiakawanan, dan sekaligus tanggungjawab akan kemajuan bersama, sehingga akan berdampak pada tingginya kinerja agency.

Learning organization mempunyai pengaruh positif dan signifikan terhadap kinerja agency, dapat diartikan bahwa semakin tinggi kesadaran perusahaan dalam meningkatkan kapasitas pembelajaran karyawan tenaga pemasaran, maka akan semakin berdampak pada tingginya kinerja agency.

Knowledge sharing mempunyai pengaruh positifsignifikan terhadap kinerja agency, artinyasemakin tinggi pemilik dan karyawan memiliki kesempatan yang luas dalam menyampaikan pendapat, ide, kritikan, dan komentarnya kepada anggota lainnya, maka akan semakin meningkatkan kinerja agency.

Knowledge sharing tidak mampu menjadi variabel intervening antara modal sosial dengan kinerja agency. Dengan demikian modal sosial hanya berpengaruh terhadap kinerja agency saja tetapi tidak melalui knowledge sharing..

Knowledge sharing mampu menjadi variabel intervening antara learning organization dengan kinerja agency, artinya semakin tinggi kesadaran perusahaan dalam meningkatkan kapasitas pembelajaran bagi karyawan, maka akan semakin menambah tingginya karyawan untuk saling berbagi pengetahuan dan hal itu tentu akan berdampak pada tingginya kinerja agency.

Atas dasar kesimpulan yang telah dikemukakan di atas, dapat diberikan beberapa saran dan diharapkan dapat berguna bagi kemajuan perusahaan. Adapun beberapa saran tersebut adalah :

Hasil tanggapan terlemah pada modal sosial yaitu pada indikator norma-norma, sehingga pihak manajemen PT Prudential Life Assurance perlu melakukan evaluasi dalam menerapkan kebijakan terhadap norma-norma yang diterapkan, yaitu upaya dari pihak manajemen dalam memberikan solusi yang terbaik dengan melakukan kerja sama antar team, sehingga terjalin komunikasi yang baik dalam meningkatkan kinerja agency.

Atasan ikut terlibat menunjukkan indikator terlemah pada hasil jawaban responden pada learning organization, sehingga pihak manajemen perusahaan 
harus ikut terlibat dalam menyelesaikan masalah yang dialami para agency dan hal itu akan menjadi pembelajaran yang lebih baik dalam meningkatkan kinerja secara maksimal.

Penghematan waktu merupakan indikator terlemah pada knowledge sharing, sehingga diperlukan untuk berbagi pengetahuan kepada bawahan yaitu dengan senantiasa bertukar pengalaman dengan sesama tim dalam menyelesaikan solusi sehingga akan bermanfaat dalam memajukan perusahaan.

Untuk meningkatkan kinerja yang optimal bagi perusahaan, maka pihak manajemen $\mathrm{PT}$ Prudential Life Assurance perlu melakukan komunikasi yang lebih secara intensif, yaitu dengan menjaga hubungan baik dalam suatu team kerja dengan didukung pentingnya learning organization dalam meningkatkan kinerja agency. Dengan terjalinnya hubungan yang baik (modal sosial) dan didukung learning organization, maka karyawan tentu akan saling berbagi pengetahuan dalam meningkatkan kinerja agency.

Teknik pengumpulan data yang dipakai dalam penelitian ini hanya menggunakan kuesioner sehingga kesimpulan yang dapat diambil hanya berdasarkan pada data yang dikumpulkan melalui kuesioner tersebut. Data yang dianalisis merupakan persepsi jawaban responden yang dapat menimbulkan masalah jika jawaban responden tidak sesuai dengan keadaan yang sesungguhnya, sehingga pada penelitian selanjutnya ditambah dengan teknik wawancara sehingga akan lebih memperkuat keakuratan data.

\section{DAFTAR PUSTAKA}

Arikunto., Suharsimi. (2012). Prosedur Penelitian ${ }_{\perp}$ Bina Aksara: Jakarta

Che Rose, R., Kumar, N. and Ong, G.P. (2009). The Effect of Organizational Learning on Organi-zational Commitment, Job Satisfaction and Working Performance. The Journal of Applied Business Research, 25(6).

Ghozali, I. (2013). Analisis Multivariate Dengan Program SPSS. Badan Penerbit UNDIP: Semarang.

Khoirini dan Kartika. (2014). Pengaruh Modal Insani dan Modal Sosial terhadap Kinerja(Studi Kasus Usaha Kecil dan Menengah (UKM) Makanan danMinuman Kota Bogor).

Makrufah, S. (2011). Pengaruh budaya, pembelajaran organisasi terhadap kinerja karyawan Hotel Bumi Surabaya. Jurnal Akuntansi, Manajemen Bisnis dan Sektor publik (JAMBSP) ISSN 1829-9857.

Mangkunegara, A. P. (2012). Manajemen Sumber Daya Manusia. Rineka Cipta: Jakarta

Mas'ud, F. (2004). Survai Diagnosis Organisasional : Konsep \& Aplikasi. Badan Penerbit UNDIP: Semarang.

Reed, K. K., Srinivasan N. D. dan Doty D. N. (2009). Adapting Human and Social Capital to Impact Performance: Some Empirical Findings from the U.S. Personal Banking Sector. Journal Of Managerial issue, 21 (1) : 36-57.

Riduwan. (2009). Skala Pengukuran Variabel-Variabel Penelitian. Alfabeta: Bandung.

Lopez, S.P., Peon, M. M. (2005). OrdasOrganizational learning as a determining factor in business performanceThe Learning Organization, 12 (3).

Simamora, H. (2012). Manajemen Sumber Daya Manusia. STIE YKPN: Yogyakarta.

Stam, W., \& Elfring, T. (2008).Entrepreneurial orientation and the performance of hightechnologyventures: The moderating role of intra- and extraindustry social capital. Academy of Management Journal. 
Sugiyono. (2012). Statistik Untuk Penelitian. Alfabeta: Bandung.

Sukoco, B. M. dan Hardi. (2013). Pengaruh Modal Sosial Dan Perilaku Berbagi Pengetahuan Dan Kinerja : Studi Kasus Di Pemasok Komponen Otomotif Astra Grup, ISSN 1412-1700, $12(3)$

Uniati, M. I. (2014). Learning organization, komitmen pada organisasi, kepuasan kerja, efektivitas penerapan sistem ISO dan dampaknya terhadap kinerja organisasi.Jurnal Manajemen Pemasaran, 8 (1).

Wahyuningrum, P. (2013). Model Peningkatan Kinerja Usaha Kecil dan Menengah (UKM) Kluster Kerajinan Kota Depok melalui Modal Insani dan Modal Sosial.

Watkins, K. E., \& Marsick, V. J. (2003).Making learning count! Diagnosing the learning culture inorganizations Thousand Oaks, CA: SageLopez et al. 